Makaleler Articles / Artikel 



\title{
UNDERSTANDING A DISPLACED COMMUNITY AND ITS ENTANGLED IDENTITY: RELIGIOUS RITUALS OF ALEVIS IN ISTANBUL
}

Yerinden Edilmis Bir Topluluk ve Dolaşık Kimlik: İstanbul'da Alevilerin Dini Ritüelleri

\section{Eine vertriebene Gemeinschaft und eine verworrene Identität: Die religiösen Rituale der Aleviten in Istanbul}

\author{
Seyhan Kayhan-KILIÇ*
}

This paper's main goal is to examine the nature of a religious belief and its entangled identity in an urban context from an anthropological perspective. My work's current focus is that the ritual practices of urban immigrants are displayed in the public space, unlike the social structure and guidance provided by a local religious expert known as a dede. Since the 1950s mass migration of Alevis from rural regions to the Turkish metropolises, such as Istanbul, the Alevi identity has been transformed into a labyrinth of socio-political obstacles and has been losing its place due to the pressures of both the state power and the Sunni and Alevi institutions. They have been losing the space that their belief attached, the clan-related (ocak) community network system, the reliance on rural divine leaders, their spiritual moods and motivations, the unique means of resolving community conflicts. The paper includes a standardized ritual and music repertoire, the revision of folklorized sacred dance (semah) elements, and a critical analysis of what can be seen as the theatrical aspects of urban cem. The second part of this paper is to understand

\footnotetext{
* Dr., Toronto-Kanada (437 987 7246). seyhankayhan@gmail.com.
} 
other reasons why Alevi identity has become entangled. Certain writings about Alevis and using concepts about Alevism, such as heterodox and syncretic, ongoing hate speech and discrimination waged against them, Islamophobia seen worldwide, have played a role in the entangled identity of Alevis. We used the ethnography research method, which is mostly qualitative. It involves participatory observation of cem rituals in Istanbul, and obtaining information through informal and formal interview techniques used during observations.

Keywords: Urban Alevis, migration, deterritorialization, communal intimacy, entangled identity. 


\section{öZ}

Bu çalışmanın temel amacı, dinsel bir inancın doğal yapısını ve onun dolaşmış kimliğini kentsel bağlamda antropolojik bir bakış açısıyla incelemektir. Çalışmamın şu anki odak noktası, dede olarak bilinen yerel inanç uzmanı tarafindan sağlanan sosyal yapı ve rehberliğin aksine olarak kentsel göçmenlerin ritüel uygulamalarının kamusal alanda gösterilmesidir. 1950’li y1llarda Alevilerin kırsal bölgelerden İstanbul gibi Türk metropollerine kitlesel olarak göç etmesinden bu yana, Alevi kimliği sosyopolitik engellerin bir labirentine dönüştü. Alevi inancı hem devlet iktidarının hem de Sünni toplulukların baskıları ve Alevi derneklerinin yaklaşımları nedeniyle var olduğu yeri kaybediyor. Alevi toplumu inançlarının bağlı olduğu doğal alanı, klanla ilgili (ocak) topluluk ağ1 sistemini, kutsal kırsal liderlere olan güveni, manevi ruh hallerini ve motivasyonlarını, topluluk çatışmalarını kendi içinde çözmenin eşsiz yollarını kaybediyor. $\mathrm{Bu}$ çalışma, standartlaştırılmış olan cem ritüelleri ve ritüelin müzik repertuvarı ve aynı zamanda folklorize edilmiş kutsal dans (semah) öğelerinin gözden geçirilmesi ile kentsel cem ritüellerinin teatral yönlerini ortaya koymakta ve cem rituellerinin eleștirel bir analizini içermektedir. Çalışmanın ikinci kısmında ise, Alevi kimliğinin dolaşık hale gelmesinin diğer nedenleri anlaşılmaya çalışılmıştır. Bu noktada Alevi toplumu ile ilgili yayınlanan kimi yazılar, bu tür yazılarda Aleviliğin tanımlanması sırasında kullanılan heterodoks ve senkretik gibi kavramlar, Alevi toplumuna karşı süregelen nefret söylemi ve ayrımcılık ve ayrıca dünya genelinde görülen İslamofobi, Alevi kimliğinin dolaşık hale gelmesinde rol oynamıştır. Bu çalışmanın yöntemi, çoğunlukla nitel olan etnografya araştırma yöntemini içermektedir. Bu doğrultuda, İstanbul'daki cem ritüelleri katılımlı olarak gözlemlenmiş ve katılımlı gözlem sırasında bilgiler resmi ve olmayan görüşme teknikleri ile elde edilmiştir.

Anahtar Kelimeler: Kent Alevileri, Göç, Yurtsuzlaşma, Toplumsal yakınlık, Dolaşık kimlik. 


\section{ZUSAMMENFASSUNG}

Das Hauptziel dieser Arbeit ist es, die natürliche Struktur eines religiösen Glaubens und dessen verworrene Identität im städtischen Zusammenhang mit einer anthropologischen Sicht zu untersuchen. Der derzeitige Fokus meiner Arbeit liegt auf der öffentlichen Darstellung der rituellen Praktiken der in die Städte Eingewanderten, was im Gegensatz zur sozialen Struktur und Führerschaft steht, die von regionalen Glaubensexperten gewährleistet werden, die als Dede bekannt sind. Seit die Aleviten in den 1950er Jahren massenweise aus ländlichen Gebieten in türkische Metropolen wie Istanbul eingewandert sind, hat sich die alevitische Identität in ein Labyrinth der sozio-politischen Hindernisse verwandelt. Der alevitische Glaube verliert aufgrund des Drucks sowohl vonseiten der Staatsmacht als auch der sunnitischen Gemeinschaften, sowie der Herangehensweise der alevitischen Vereine seinen angestammten Platz. Die alevitische Gesellschaft verliert die natürliche Umgebung, an die ihre Glauben geknüpft sind, ihr klanbezogenes Gemeinschaftsnetzwerk (Ocak), ihr Vertrauen in heilige ländliche Anführer, ihre spirituelle Geisteshaltung und Motivationen und ihre einzigartigen Wege Streitigkeiten untereinander zu lösen. Diese Arbeit legt die standardisierten Cem-Rituale und dessen Musikrepertoire und gleichzeitig durch Untersuchung der Elemente des in folkloristische Form gebrachten heiligen Tanzes (Semah) die theatralischen Seiten der städtischen CemRituale dar. Außerdem beinhaltet sie eine kritische Analyse der Cem-Rituale. Im zweiten Teil der Arbeit wurde versucht die anderen Gründe zu verstehen, die dazu geführt haben, dass die alevitische Identität eine verworrene Form angenommen hat. Hierbei haben manche veröffentlichte Artikel in Bezug auf die alevitische Gesellschaft, Begriffe wie „heterodox“ und „synkretistisch“, die während der Definition des Alevitentums in dieser Art von Artikeln verwendet werden, die Hassreden und die Diskriminierung, die der alevitischen Gesellschaft entgegengebracht werden sowie die Islamophobie, die überall auf der Welt zu sehen ist, eine Rolle darin gespielt, dass die alevitische Identität einen verworrenen Zustand angenommen hat. Die Methode dieser Arbeit beinhaltet die ethnographische Forschungsmethode, die mehrheitlich qualitativ ist. In diesem Sinne wurden die Cem-Rituale in Istanbul durch Teilnahme beobachtet und währenddessen Informationen durch formelle und informelle Gesprächstechniken erlangt.

Schlüsselwörter: Städtische Aleviten, Migration, Deterritorialisierung, gesellschaftliche Nähe, verworrene Identität. 


\section{Introduction}

Alevi is a religious community that mostly found in Turkey, the Balkans, Syria, Iraq and Iran. In the Balkan area, they are generally known as the Bektashis. Today, we can see them in different areas around the world because they migrated from their hometowns to major cities or abroad such as Germany, England, France, U.S., Canada... etc. It is necessary to try to understand Alevism in both rural and urban contexts together with these migrations. Here my research object is about ethnography of the nature of rituals and identity of Alevis as a religious community in the urban context, specifically Istanbul. The focus of my studies is to illustrate the obstacles urban migrants face in confronting a more public display of Alevi's expressive culture that differs so much from the communal intimacy of regional modes of ritual practices ${ }^{1}$.

Over the past third decades, there has been considerable extinction and erosion concerning religious and cultural thinking in Alevism. In the rural context, Alevis are surrounded by their cultural and religious nature that they come into existence around sacred places such as dargahs, tombs and the graves of their spiritual ancestors. In contrast, in the urban context, the Alevi population reconvene around the Alevi institutions to confirm their identity by performing standardized rituals. The insiders are wondering if their traditional belief is going to 'teeter on the brink of extinction' (Davis, 2009: 3) in the urban context. That, of course, would not mean that things were going well in the countryside. What it means that is explained by Davis (2009: 3) “...we within a generation or two, we will be witnessing the loss of fully half of humanity's social, cultural and intellectual legacy. That is the hidden backdrop of our age." Hence, not only the Alevis but also the many other cultures around the world are losing their natural thinking. However, Alevi transformation

1 While I was writing this text, the paper entitled "Alevi Entangled Identity and Religious Rituals in Istanbul" was used as reference. Kayhan Kilıç, S. "Alevi Entangled Identity and Religious Rituals in Istanbul" The Society for Ethnomusicology 64th Annual Meeting, Bloomington, Indiana, 2019. Retrieved from https://cdn.ymaws.com/www.ethnomusicology.org/ resource/resmgr/docs/sem_2019_abstract_book, fin.pdf

Short report of the research was published in Culture Newsletter in Canada in 2018.

Kayhan Kilıç, S. "Entangled Identities: Ritual Performance of Alevis in an Urban Area" Culture Newsletter, Vol. 12, No. 2. 2018. Retrieved from https:/ / cascacultureblog.wordpress. com/2018/12/19/entangledidentities-ritual-performance-of-alevi-in-an-urban-area 
does not follow the natural paths because they are the subject of controversial public and political debates, especially in the urban context.

There are ongoing arguments concerning Alevi identity, such as Alevis in Islam and outside of Islam. These arguments can be seen as part of the entangled identity of some Alevis today. Moreover, understanding Alevis in the urban context contributes to figuring out the reasons for the extensive discussions on Alevis. This paper will not directly focus on reviews of Alevis with Islam/without Islam, but it talks about many reasons why the arguments around them exist.

Alevis have been studied in the urban context by scholars from different perspectives such as political scientists, historians, sociologists, anthropologists, folklorists. However, in this paper, all questions are derived from clan-related hearth (ocak) identity and rituals in city life to understand why their identity became entangled. It seems, there are a few studies related to ocak-centred and concern about comparisons in urban studies on Alevism from an anthropology perspective.

Before going any further, I shall explain two concepts. One is the importance of hearth (ocak) in Alevism, and the second is why I preferred the idea of entanglement in this paper. The ocak is a clan-related community that represents the sacred lineage of a charismatic belief leader and their supernatural powers. Although the underlying meaning of the ocak is hearth, ocak has multiple implications concerning the cosmological framework, collective identity, hierarchy, structure, rules, and rituals. As for the concept of entangled, which is the focus of the text, the chaos that they experience in reproducing and reinterpreting the Alevi identity and culture in the city environment identified as entangled.

\subsection{Background of the study and method}

Here, it is necessary to explain something about my ethnographic method and how I conducted my study and my preferences. Over the past ten years, I have focused on the hearth (ocak)s to understand the Alevis better because the Alevi rituals are based upon the tradition of the clan-related (hearth (ocak)). The second part of my studies are how Alevis re-affirmed and reacted to their rituals in urban areas. Hence, the comparison between the traditional rituals and the urban rituals provided by using enriched fieldwork knowledge of their performances. 
The ethnography research method, which is mostly qualitative involves participatory observation, and informal and formal interview techniques were used during collections of cem rituals in Istanbul. My observation is based on my participation in cem rituals. The equipment included photographs, video, and sound recorder. Fieldwork studies have been going on for more than ten years, started in 2006, continued to 2017 in Karacaahmet Sultan Dergah and Sahkulu Sultan Dergah, Ikitelli Cemevi, Tasdelen Cemevi, Okmeydani Cemevi and Sarigazi Cemevi. Intensive fieldwork studies were done between August 2014 to April 2017. To summarize the method, the information has been collected by the ethnography method and literature review then analyzed by the interpretive approach of anthropology.

As a scholar, I have spent more than a decade investigating the sacred assemblies (cemler) of Alevis in rural areas of Turkey. While doing Alevism studies in the countryside, I observed cem rituals especially in city centers such as Istanbul. This offered the opportunity to compare both. For example, one of my fieldwork researches was done on Seyyid Ali Sultan Ocak in the Camluca district. Alevis have been relatively apart from the fear of losing the ritualistic performances there. This region was physically and religiously self-enclosed. Çamlica district had a higher elevation and smaller than Okesu where is the nearest Sunni Muslim area. Although Çamlica was not far away from the city center of Kütabya and the transportation was provided from the city to the district, I felt the community was in the middle of nowhere. When I first arrived in the area, the weather was cold, and the winter was snowy and soggy. There were shallow forests with large conifers - specifically pine that is a promenade for visitors. There was a huge rock at the entrance of the district. The Villagers told me that when the Ottoman soldiers came to raid their ritual, the rock closed the way, much like a curtain. The soldiers could not find a way to capture their elders (Kayhan Kılıç, 2014: 72).

Villagers have lain on the shoulder of a piney hill. They were talking about the stories on the miracles of Seyyid Ali Sultan who saved people as well as the land. I have listened to too many stories about the relationships with the Ottoman states as well as the state of the Republic of Turkey and their Sunni neighbors. Those stories have included mostly exposed to discrimination and then disguised ethnic and religious identity. One day, I got lost while trying the way where to go to Camlica village. Although I was a researcher, not a villager, I refrained from asking someone to find the Village due to the stories that I have listened to by the Camlaca villagers. 
When I asked the people in the city center how I could go to the village, I was unsure if they would help me. Those narratives were about what they had felt when Sunnis discriminated against them because of their belief. All their feelings have overlapped with mine as an Alevi. However, there was a difference between these villagers and me as well as other traditional Alevis in my research areas. Namely, I am not initiated to a hearth (ocak). I was born in a small village but grown up in the city of Istanbul. I am a person who lost her relationship with her ocak and spiritual leaders. I am culturally Alevi, but I am not defined in the traditional Alevism. From this perspective, I believe that my view for both rural Alevism and city Alevism will expand the understanding of this issue. Thus, Wagner (1975: 78-86) says that you discover yourself while looking at others. My research interest in Alevism is for my discovery of myself and 'others'. At this point, Abu Lughod (1991: 466-479) claims that the problem appears when a person identified both 'self' and 'other'. Hence, those Alevis feel the same when they come to city life if they do not belong to an ocak. That can also be explained by the concept of Turner (1969: 95) is that liminality which means "neither here nor there." When Alevis move from rural areas to the city, they feel themselves neither 'self' nor 'others' in terms of being Alevi. They think their situation is in between. That is the challenge of living in a city.

\section{A labyrinth of socio-political obstacles and the challenges in the city}

Alevis have migrated from their rural areas to urban cities since 1950. Alevis mostly live in the closed and ethnic districts such as Gazi, Zubeyde Hanim, 75. Yil, Yunus Emre,1 Mayis, Okmeydani, Ugur Mumcu, Alibeykoy in Istanbul. They have established worship places (cemevi) there. It must be underlined that Alevis are organized via cemevis and Alevi institutions in Istanbul. The worship places such as Karacaahmet Sultan Dergah and Sahkulu Sultan Dergah some of the most famous and historical places in Istanbul. Although Alevis have worship places and institutions, it seems acculturation has been problematic as Alevi identity has become entangled in a labyrinth of socio-political obstacles and the challenges and pressures instigated by Sunni and Alevi institutions. They often lose their spiritual leaders (dedes), clanrelated identity and the network system named hearth (ocak), the place of the tomb (yatır, türbe, ziyaret) where their belief attached and rituals performed.

Istanbul is one of the significant and sophisticated cities in both Europe and Asia. Not only Alevis but also Sunnis migrate to Istanbul every year. Istanbul is like an ethnic urban village people occupy distinct territories, in which there is a high degree 
of social interaction with others, but their functions are too effective communities. Istanbul is not just the city that must be understood in the context of policy, religion, culture, and the economy. It is a mosaic of social worlds characterized more by alienation and disorganization than by social cohesion and organization. Istanbul is characterized by social change, sometimes rapid, threatening the traditional communities that had not been built with the spread of urban-industrialism and capitalism.

Urban is different than non-urban. In urban life, people lose their sense of community. Their identity become tangled because they feel the in-between metropolitan city and their hometown. Their status being inside or outside (Relph, 1976). They may not even be able to agree on what are the geographical limits of the place, its boundaries. Attachments to new geography are varied between members of the community. Some members of the community feeling a much higher degree of attachment with the local place than others. However, the community is about similarity, but it is also about differences about being an insider or outsider. Individuals and groups adopt spaces with different meanings.

Istanbul is the city that could be linked often to patterns of social interaction. Alevi community, then, became intricately involved with how social behavior within the city was organized, and indeed could be understood. Hence, Alevi community exists contradictions to the epistemological problems that have arisen in their identification. According to Walzer (1995), urban social life is not so universal. It is characterized by atomistic. Although supportive social networks are still persisted in the city and Alevi institutions are one of them, urban life is pretty much individualistic rather than collectivist. However, social network groups are comprehensively divided into a network of territorial communities in distinctive zones in virtually all cities. It is not realistic to say that social interactions are generalized amongst groups to give a common social purpose in city life. More than a century ago, Weber (1963) stated that due to the increased mobility, social interaction replaced with extra-locally in the 'non-space urban realm.' Hometown or "countrymen” institutions (yöre dernekleri or yöresel dernekler) is one of the examples for extra-locally in the 'non-space urban realm’ (Hersant \&'Toumarkine, 2005).

I want to interpret city life from the Tönnies's concepts of Gemeinschaft and Gesellschaft. Gemeinschaft indicates intense interaction, which is personal and based on primary social relationships. However, Gesellschaft individuals had become more 
independent on one another because of the division of labour and the deepening effects of capitalism (Paddison, 2001: 195-196). The city has a complex structure when we look at it in terms of interaction or being independent. Istanbul is an interactive city in terms of the relationships that ethnic groups maintain within their community, but it is distant and individual in the relations amongst groups. Here, one of the Alevi institutions' functions were similar to countrymen institutions that ensure if Alevi immigrants meet and then interact with their communities in the city.

It is necessary to evaluate the political relationship between ethnic groups and the state in the city. Politicians and government agencies can direct the new relationship between the state and the community. Any critical understanding of the place of the community needs to draw out an appreciation of both. However, these two aspects are unrelated. Indeed, the benefits of Alevis have become harnessed by political debate. In the city, the Alevi community has been faced with the conflict. The Alevis complain about the hate speech and discrimination waged against them. For example, according to interviewers, AKP (Justice and Development Party) regime denies the worship place (cemevi) and sees those who use a cemevi instead of a mosque to worship as atheists. Alevis criticize that the longstanding services provided for the Sunnis by the Turkish regime. Those issues are concerning the allocation of resources that characterize the city.

According to Appadurai (1996: 48), "the groups migrate, regroup in new locations, reconstruct their histories, and reconfigure their ethnic projects." Appadurai (1996: 48-49), coined the term ethnoscape, which means a "changing social, territorial, and cultural reproduction of group identity." That is to meet the needs of the Alevis. They have migrated to the metropole from their hometown, and they adopted a new form of collective understanding. The deterritorialization exists in the urban context that contains understanding the cultural distance from the locality, work of imagination, develop transnational cultures and set some hybridization into a new life (Appadurai 1991: 191-210). The question is how the change shall define. Is it continuity of culture, alteration, or adaptation under the new circumstances? (Glassie, 1995: 395). Hence, Alevis lose their cultures or localities through globalization in the cities, whereby now they are trying to find the local within the global. 


\section{Losing the unique Alevi terminology and the meanings of rituals}

In this section, I shall talk about more public display of Alevi expressive culture that differs so much from the communal intimacy of regional modes of ritual practices and the guidance provided by a local religious specialist known as dede who descends from a saintly lineage. As I mentioned before, Alevis has been losing a solid, clan-related (hearth (ocak)) community network system, also the rural spiritual leaders and their unique means of leading rituals. Likewise, these are the cause of the theatrical aspects of the urban cem with its standardized liturgy and musical repertoire, folklorized sacred dance (semah). Hence, I shall talk about how they memorize their religious identity and practice their rituals in urban space.

According to Assmann (2001: 47-48), the new generations do not perceive religious practices as a tradition. It seems many ritualistic performances lose their meaning, and they do not go beyond habit after a particular time. For example, the kissing threshold at the door of the tombs or kneeling before dede have lost sense, and that becomes just a habit. Hence, behaviours which have adopted before will continue to take a new form. Thus, it is necessary to keep giving examples of the religious reconstruction of Alevis in urban space.

\subsection{From the traditional ocak based community to a new network system}

All Alevi tradition is theoretically based on the belief of clan-related hearth (ocak) and dede, the practice of sacrifice and cem ritual. Clan-related hearth (ocak) and spiritual leader (dede) are terminologically the main in the Alevi belief. Linguistically, the word hearth (ocak) is created from a combination of two words: fire as a source of heat, light, and cooking, and a place where people live. The hearth (ocak) itself gets anthropomorphic characteristics, at the same time. In Alevi belief, sacrifice is always offered to hearth (ocak) and Hakk-Muhammad-Ali. A roaring fire has the meaning of existence, blessing, order and stability. Belief is strengthened and ameliorated around the fire. That is because Alevis believe that they never let the light blow out (Kayhan-Kılıç, 2014: 173-174).

In some of the villages, I have observed that hearths were inside the room where rituals have been performed. Sacrifice is the primary practice that is offered 
to hearth (ocak). In the cities and rural areas, there are large kitchens for cooking and preparations for the ritual food. In some of the villages, I have observed that hearths were inside the room where rituals have been performed. For each ritual (cem), it depends on the needs, Alevis sacrifice (ttğlamak) one or more sheep. The spiritual leader (dede) continues to pray (gülbeng) for the sacrifice. The cem ritual continued, while sacrificial meat was cooked in a large kettle on the stove. The meat of the sacrifice and meals, also fruit or appetizers that Alevis bring to their worship place (cemevi) is also called shared food (lokma). Alevis believe they must practice sacrifice and share with others for maintaining intergroup relations, social order, reconciliation with supernatural power, forgiveness for making an excuse, obtaining their wishes or giving thanks. In cities, sharing food, for instance, cake, fruits and nuts, is more common because it is easier than sacrificing animals. However, the new generations are discussing sacrifice in terms of human rights, whether it is correct to practice.

I shall explain the traditional rituals of the Alevis are organized through clanrelated hearth (ocak)s. Every hearth (ocak) has a historical, charismatic and spiritual leader. Spiritual leaders (dede) descend from the Ahl'al Bayt and Twelve Imams. Hence, ocak symbolizes dede families, their past and spiritual roots. Moreover, hearth (ocak) is a socio-cultural and belief institution for Alevis. Spiritual leaders (dede) has the responsibility to carry certain acts and forms in rituals and daily life with believers (talip).

Each Alevi belongs to hearth (ocak), by birth. Hence, hearth (ocak) identity is an ascribed status. However, formal relationships with hearth (ocak) and the responsibilities began when individuals justify their sense of belonging by initiating into the hearth (ocak) in front of the spiritual leader (dede) and the believer (talip). Then they periodically come together to construct their realities. If there is a person who has not initiate the hearth (ocak), the identity will be invalid. Hence, Alevis have status by birth, but they have no belonging to the hearth (ocak). This religious and social order has been damaged because of socioeconomic reasons and migration. Many Alevis have forgotten their hearth (ocak)s and spiritual leaders (dede)s. At this time, many tasks such as teaching and performing religiously, cooperating and organizing socially, amongst Alevis are provided by many foundations and institutions in city centers. 
There are two types of Alevi institutions found in city centers. Karacaahmet Sultan Dergah and Sahkulu Sultan Dergah are well known historical places. The tombs of two saints are physically there and represent the historical and spiritual entity of Alevis, unlike Sutanbeyli Cemevi or many others that are newly built in the city of Istanbul. The historical places' existence contributes to the continuity of traditional belief systems and identities of Alevi immigrants who have lost their natural areas to which their beliefs depend.

All those Alevi institutions are also similar to the community centers in Canada, such as the Native Canadian Centre of Toronto. Community centers provide social, recreational, cultural, and spiritual services to their members. For example, Alevi immigrants from Toronto founded Canadian Alevi Culture Center in 1996. Although this institutions' activities show similarity with the Alevi institutions in Istanbul, living in the diaspora prevents them from providing religious services for the Alevi members. However, members of the institution can express their feelings and experiences with others who have the same status in Canada. Together they organize activities such as seminars, concerts, memorials. Also, those who lost their close relatives outside of Canada accept condolences here.

Most importantly, according to Canadian Alevis, they can express their belief in a free and democratic environment. However, most of the meetings that I have been in the Alevi institutions, Alevis have complained that lacked state support. For example, many institutions have difficulty in meeting their electricity and water expenses. There are also concerns about security, which is the fundamental human right. All my interviewers have agreed upon the pressure of the state over the Alevi institutions. They were referring to the fact that the mass murders have been since the Ottoman Empire. However, according to the interviewers, the current government has been providing ethnic discrimination against Alevis more than before. One of the most critical duties of Alevi associations is to organize memorials for each mass murder and to ensure that the Alevis remain alive from their memories.

Alevi institutions consist of many services, such as organizing cem rituals, holding funeral ceremonies, teaching ritual dance (semah) courses, especially for young Alevis in city centers. They organize annual assemblies such as remembrance days of Dersim, Maraş, Sivas, Çorum, Gazi massacres and the International Women's 
Day. Some of the ceremonies and feasts have the symbolic representational forms that create a common perception amongst Alevis (Connerton, 1999: 85, 113-18). Among those, one of Alevi institutions' essential tasks is organizing courses such as instruments and ritual dance. These courses are popular amongst young Alevis and contribute to the acculturation process. However, the ritual dance (semah) and ritual instrument (bağlama) training, has been standardized by the Alevi institutions, the religious leader (dede), and the educators who give the instruction. Hence, courses may not reflect the richness of repertoire and dance figures of Alevi ocaks.

Every hearth (ocak) acknowledge is unique to itself, even though they are not unique to a fundamental structure. The Alevis express this by saying, "The path is one. A journey is a thousand and one." Certain acts or forms, in some rituals, may differ from one hearth (ocak) to another but, the structure remains beyond all hearth (ocak)s. However, rituals are in a city too structuralized and standardized, unlike rural areas. Alevis are more concerned with ethics and assists people in knowing what means right and wrong for Alevis in complicated city life. Alevi institutions provide spiritual leaders (dede) and organize rituals, so that Alevis may continue to communicate with their spiritual world. At this point, in the city center, one of Alevis' basic needs is a sense of belonging. Only Alevi institutions have had a dominant role in filling individuals' needs to belonging to a community. It is not realistic to expect that Alevis could keep and follow their hearth (ocak) identity in the urban context. However, they may practice some of their rituals in a new environment of the city.

At this point, Alevis create their sacred spaces in the city environment, and they reinterpret the space, which is necessary to keep their religious identity. According to Appadurai (1996:48), the term ethnoscape, which he coined, means a changing social, territorial, and cultural reproduction of group identity. In the city centers, Alevi immigrants often lose their spiritual leaders (dedes), group identity or clanrelated hearth (ocak) and space where their belief is historically and spiritually attached. However, when Alevis migrated from rural areas to city centers, they reunite in the Alevi institutions to reconfigure their histories, renovate their religious ideas and practices under the new circumstances. Reproduction of Alevi identity contains many struggles to create a sacred place and come together with people who have the same identity. Many Alevis need to find a spiritual leader (dede) to perform religious practices there. While there were few numbers of worship places (cemevi) at the beginning, today, there many cemevis exist in almost every district in Istanbul. 


\subsection{Cem rituals in city life}

The cem, which means assemble, is a central ritual practice in the Alevi belief. Alevis perform their rituals in a place called the cemevi, a word which means gathering a house. The cem ritual of the Alevis is based upon The Assembly of Forty Saints (Kirklar Meclisi). I have recorded that when a spiritual leader (dede) prays, he commonly says, may their cem be itself, may their cem be Kirklar cem. "Bizim cemimiz. Kirklar Cemi olsun!"

The Assembly of Forty Saints (Kirklar Meclisi) is a mythological story about the miraculous journey of the prophet Muhammad from the secular world to heaven (miraç) to meet and talk with God. Alevis believe that miraç is the origin of the cem ritual that the minstrel (aş1k) tells this story through a song called the Mibraclama. Although there are very few differences such as melodies, words between the form Mibraclama, the meaning and structure remain the same amongst Alevi ocaks. However, the content of the ritual, mutually accepted purposes, the persistence in practices, effervescence of the participants and the numerical value of the participants are different in the cities.

Alevis have stratified in the city life from the first migrants of the Alevis to the present. I have observed many rituals in Istanbul, and there are differences among the participants in terms of age, gender, economy, status, education, political opinion, desires and needs. However, rural life was much more homogeneous. Hence, some of the Alevis have difficulties believing sacred symbols, meanings, ancestors and stories such as Kirklar Meclisi and Mirac. For example, Alevis believe that when the Prophet Muhammad arrived at the highest level of heaven, a lion appeared on his road. The Prophet wondered, but he heard a voice that called and instructed him to put his ring into the mouth of the lion. Prophet followed the instruction. The lion took the ring and then calmed down. Muhammad continued to on his way. He then met and talked with God. Prophet Muhammad saw his ring on Ali's finger while he had an ecstatic dance in the Krrklar Meclisi. Some of the Alevis think that this story is meaningless. For example, they do not believe that one person can transform from human to animal and vice versa. Mythological stories and historical events are the characteristic features of the Alevi spoken oral tradition. For example, as an integral part of the Karbala Massacre commemorative ceremony is reflected in ritual practice, it is still alive and well in their collective memory. 
Cem ritual is a socially agreed-upon way that shapes people's everyday life in many ways. For example, every ritual must start with mutual consent (razllik). The spiritual leader (dede) asks a question more than once during the ritual if participants are satisfied. If any individual does not give consent, the cem ritual is not initiated by the spiritual leader (dede). All participants are responsible for ensuring peace during the ritual without exception. However, in the urban context, people do not know each other. Hence, mutual consent as a ritualistic part is symbolical and replicates without inner meaning.

The rituals maintain conformity and fertility amongst the cities. It seems more like a union (birlik) cem rituals. Alevis collectively offer a sacrifice and prepare food together during the rituals. Hence, union (birlik) cem rituals are very functional in city life but, it is not performed to maintain control over the society, unlike rural examples. The calendar rituals such as Abdal Musa, Hizır, Nevruz, Muharrem cem ritual is also performed in the city. However, life-change rituals such as initiation (ikrar), interrogation (görgü), reintegration of deviants, (düşkünlük kaldırma) cem rituals are not usual in the urban context. Most of the Alevis can not perform deceased (dar) cem ritual at the time of death that is performed after death, the descendants' survivors try to remain comfortable themselves.

In the urban context, Alevis cannot perform all the twelve services (oniki hizmet) that are the backbone of all cem rituals. These twelve services symbolize the twelve imams who are descendants of Imam Ali and his spouse, Fatıma. One of the twelve services (gözcü) represents a person who controls discipline in the ritual is still performed in the cem rituals of the city.

In recent years, Alevi institutions have been letting the elements of different religious identities into the Alevi rituals celebrated in Istanbul. For instance, semah is a spiritual dance of the Alevis. In a cem ritual, the minstrel (aş1k) recites the words from the mibraclama. When minstrel (aş1k) quotes the ninth quatrain of mibraclama ${ }^{2}$, and the participants hear the aşı state, change their seating position;

2 In Original Turkish language:

Muhammed kalktı ayak üzre server

Oldu gözü gönlü enver

Bu sirrr eyledi izhar

Habibe Hikmetullahi 
The Prophet Muhammad stands up.

His eyes and heart are radiant.

The mystery was disclosed to Muhammad, who is a lover of God.

In turn, participants kiss the place (meydan) where the ritualistic performances expressed, stand up and assume the dar position. They imitate what Prophet Muhammad did on his journey.

In the previous quatrain, Hatayî states;

The Forty drank sweet water.

They performed the Kirklar Semah.

They felt ecstatic with a sense of love.

Both men and women who perform the sacred dance (semah) communicate with each other and the spiritual world through words, movements, gestures, rhythms, and melodies. Kirklar Semahı has been standardized in recent years. However, in ocakcentred Alevism, each ocak is unique. Even though the words and melody are in a particular structure, they differ from ocak to ocak. On the other hand, the sema is a well-known ritual dance of the Mevlevis that they are Sunni and Sufi-order within Islam and still active in Turkey. The whirling dervishes perform the sema with the accompaniment of musical instruments, such as flute and tambourines. Only males are allowed to dance. Today, the sema performs in the Alevi cem ritual along with the Alevi sacred dance of the semah. While the semah dance performers turn in a circle, in the cem ritual, there is a sema dance performer also. That is a kind of composition. Hence, these kinds of rituals are one of the examples of the tangled identity of Alevis.

In most rural areas, and each hearth (ocak), both males and females are uniquely dressed. They wear the same during the cem ritual with their daily life. In urban areas, the Alevi institutions determined in clothes that participants wear while performing the sacred dance (semah). However, in recent years, female performers wear black clothes, and they cover their heads with black in cem rituals. They are twirling while

Kırklar bir şerbet içtiler

Can ile baştan geçtiler

Cazibe aşka düştüler

Etdiler Kırklar Semahı 
performing the sacred dance (semah), and their clothes are very similar to the Caferi female clothes.

As I mentioned before, social interaction is functional in the city center. When the Alevis emigrated to the cities, they were exposed to political debate and social pressures from workplaces and schools. Alevis, who were migrated from a mountain village to Istanbul, might have never faced the political discussions in their homeland. Islam always criticizes Alevis that their religious performances are not standardized under Islam. Hence, Cem vakfi and other Alevi institutions try to standardize ritual activities to accomplish universal and homogeneous structures amongst Alevis in urban areas. In the traditional Alevi rituals, people are mostly oriented directly towards face-to-face, and while seated, men and women are not separated. For example, in the rituals of Tahtaci Alevis, each female and male participant line up side by side. However, in the urban region, even in the same cemevi, I have observed different applications regarding that.

In the traditional cem rituals, participants sit in a circle and are oriented directly towards each other, face-to-face, known as cemal cemale. In many urban and rural cases, participants all remain within the circle, but men and women are separated. The first circle is called the Circle of Forty (Kirklar Halkasi) that refers to the Assembly of Kirklar. In the story told by the Alevis, the Kurklar Assembly is composed of women and men. However, only men can sit in the first circle, which is the same in urban and rural contexts. In the rural context, a person who is not initiated and questioned cannot sit in the first circle. Alevis cannot follow that in the urban setting because the city is a crowded place. Neither spiritual leader (dede) nor participants know who is initiated who is not. Hence, rules are not too strict in the urban context. Likewise, in the urban context, no one can be sure if there is a denounced individual in the cem ritual.

At least, during the cem ritual, spiritual leader (dede) establishes a highly hierarchical structure, but dede's place has never been higher than the participants. In traditional cem rituals, all participants were sitting in a circle, including a dede. I mentioned the Kırklar Halkası before. Spiritual leader and minstrel were also in this circle. However, they all sit on the cushions over the floor. There is only a post, upon which the dede sits. The grandfather's place would be on the right from the door to the entrance. In contrast, spiritual leader and minstrel are sharply separated from the participants. A large and quiet seating is designed for them. 
In the rural context, during the winter, Alevis work less, and they are more available to perform cem rituals during this season. Typically, the rural area's economy is family farming and animal husbandry in the regions where Alevis live in Turkey. I'm afraid I have to disagree with Diamond (1994: 106), who claims that agriculture is an efficient way to get more food for less work. According to my observations, those who work with agriculture also deal with animal husbandry. There are no concepts such as weekend leave, holiday leave, overtime in Turkey for the farmers and ranchers. However, villagers may arrange their time to perform their rituals during the winter. Besides, in contrast to the urban context, rural Alevis can schedule their time without asking their bosses. In the urban area, Alevi individuals work in a full-time job, and neither their time nor they are flexible. For example, farmers who spend the whole night worshiping the next day do not have to explain to anyone for their low performance.

In the present day, ritual timings have been altered both in the urban and rural areas. When we look at the rural area, it may seem that the population of villages has decreased due to migration. They are available to perform cem rituals on weekends and in summer when immigrants return to their village for a holiday. Typically, cem rituals are performed Thursday evening and end after Thursday midnight, on Friday. Alevi participants perform Friday night cem ritual to work together and educate their youth, save their culture and their group identity. in the city. Although the Muharram/ Ashura cem (Aşure Kurbanı Cemi), the Navruz/Nevruz cem rituals are annual, in the city, Alevis mostly prefer to perform all rituals on weekends. All rituals had their sacred time and scheduled during the year except life change rituals. The sacred time of the rituals, believed to be determined by the spiritual world, has left its place to the time which is determined by the secular world, according to social, economic al and political conditions.

\subsection{Threshold}

Alevis believe the threshold at the door of worship places is sacred and it is forbidden to step over it. Any participant entering the ritual room must first kiss the threshold this is a ritualistic performance named niyaz. The threshold has been encoded with deeper meanings that it separates the holy place (sacred) from the (profane) outside world. For instance, the threshold represents the sacred path's entrance, which means the principles and spiritual way of Alevism. Four sides to the door symbolize each of four holy persons Prophet Muhammad, Shah Hassan and 
Shah Hussein, Haji Bektash Veli and God. It is very metaphoric and ritualistic. When a person arrives at the spiritual truth, they reach unity with divine reality. However, the threshold lost its more profound meaning in the urban context. It symbolically performs because Alevis have difficulty in following a spiritual way of Alevism.

According to Asad (1983: 239) "symbol (any object, etc.) is differentiated from but linked to the conception (it's meaning)." For example, some of the visitors in the Karacaahmet Dargah and Sahkulu Dargah told me that they did not know in-depth what the threshold symbolized. Others said they were kissing the threshold because they wanted to express their respect to the saints before entering. I observed that some people did not perform niyaz before the threshold, unlike others. Then they said that the performance had no meaning for them even if they were believers. Many other physical objects have lost their meaning and the functions as well. For instance, belt tying (kemerbest/tuğbend). All initiated participants in the cem ritual must tie their belt. They do not participate in cem ritual without tiğbend. It is first tied in the initiation (ikrar) cem ritual. Hence, belt (kemerbest/tığbend) symbolizes the person who has initiated status in their hearth (ocak) and questioned in front of the spiritual leader (dede) and the congregation once in a year. However, there is no obligation to wear a belt in the city because not all the cem ritual participants have the initiation. In the city of Istanbul, I observed participants who perform the sacred dance (semah) have their belt (kemerbest/trğbend), which is usually made of green cloth, even though they have not initiated to an (ocak). However, The Alevi institutions struggle to save traditional clothing both for females and males. Among those who attended cem ritual, some did not know what the belt (kemerbest/tiğbend) meant. Despite all these, even if these physical objects are symbolic and their meanings change, they are all part of the city Alevism. Therefore, the relationship between symbol and meaning continues in away. However, we shall pay attention to the hearth (ocak) system of Alevis to better understand the nature and deeper meanings of physical objects.

\subsection{Musâhiplik as a fictive relationship}

Musâhiplik is a brotherhood relationship between two couples that also refers to close relatives in a particular social and religious context. Musâhiplik is categorically a different kinship relation. One significant difference is that musâhiplik is not a bloodbased kinship. It is a kind of imaginary relationship. So, someone might say that a person can be his brother. However, they both must have Alevi identity and ability 
to initiation. Although musâhiplik is not a bloody relationship, there is supposed to build a brotherhood relationship between not only two people both also amongst their families. In the first stage, two men are supposed to know each other as a close friendship, and then they can decide whether to establish a brotherhood relationship or not. The idea is very similar to Tory Islanders. The word for friend is the same as the word for kin. So, logically, a friend is also kin (Miller, Esterik \& Esterik, 2010: 202-203).

Alevi rules of the act do not allow marriage or sexual relations between musâhip's children. That is a sort of incest taboo (Strauss, 1969) or a rule prohibiting intimacy or sexual intercourse between musâhip's children. The incest taboo between musâhip's family is encompassing more than this. We might say their children and close relatives cannot get married or sexual intercourse. That is also similar to a kinship established by breastfeeding. If babies nursed by the same woman, they cannot marry each other.

Although being Alevi is an ascribed status, each individual must struggle to get an exception by the community. Then, they become a believer (talip) when they initiate their hearth (ocak), which is named the initiation ritual (ikrar cemi). Hence, if any individual wishes to become an initiate, they must find a fictive brother (musâhip). The most crucial step for being musâhip is sacrificing ram or sheep in a ritual. Initiation (ikrar) and musâhip cem are the ways that individuals step over to the spiritual path. After that, they may perform a questioned cem ritual (görgü) every year to follow the rules.

That is a very long and challenging process. Candidates need a person locally named mürebbi, k1lavuz or yağlık rehberi who leads to the way to prepare them for the spiritual path. According to the Alevi belief system, the believer who does not have the musâhip relationship is not accepted as Alevi. They cannot participate in rituals. However, Alevis, who have the musâhip relationship, can access and understand both the external (zahiri) and internal (batini) knowledge of faith. Having musâhip relationships determines the place where the person will sit in the cem ritual. For example, the participants remain in a circle during all cem rituals. Only women who have musâhip are allowed to sit behind the circle that men who have musâhip remain. Some of the Alevi ocaks, if a woman has musâhip relationship, can perform Kırklar and Kerbela Semah that are ritual dance in cem. 
Musâbiplik is a stringent rule in the Alevi belief system because it functionally helps people to maintain solidarity and social control amongst believers. There are supposed to be certain agreements between two families. For instance, they must take economic and social responsibility for each other's family's moral values. It seems this service is not possible to continue in the cities. One of the reasons is that Alevis cannot support each other because social and economic conditions are so challenging in the city. Second, it is difficult to find a mentor (rehber) who has the spiritual knowledge and the rules of the way to prepare brothers for the initiation ritual and monitor them if they follow the rules. During my informal interviews, I have recognized that musâhip relationship remains in the city context, not as ritualistic, but they keep that as socially and culturally.

\subsection{Düşkünlük: Resolving Community Conflicts}

Fredrik Barth (2001: 12-7) states that each community has the mechanism of exclusion and inclusion. This mechanism works with moral and social values. Thus, there are invisible borders between cultures. Furthermore, ethical and social values are agreed-upon rules to order social life and maintain social control to ensure conformity, over the community (Garland 1996: 781). Like Amish and Mennonites, traditional Alevism relied on internalized social controls far more than most other similar groups. They have no police force or the legal system. Spiritual teaching and group pressure maintain the social order.

Morals and norms are an accepted standard for how people should behave they are unwritten and learned unconsciously through socialization. All Alevi hearth (ocak) have patterns which include, for example, the expectation that believers (talip) should follow their mentors' (mürşit) advice. If a member veers from correct behaviour, punishment such as ostracism (düşkünlük) which is a concept that means being deviant in Alevi belief system may be applied. Düskënlük is also a situation related to the ocak system, and its existence is performative more than a doctrine. A deviant person can not participate in any rituals. They are excommunicated and isolated, not only from the rituals but also from the community. That is interpreted as the Alevi People's Court. Kuipers (1990) reported a similar attitude that in nonstate societies if a person breaks a promise, that affects the whole community. Punishment may come from ancestors in different forms, such as illness, death, damage, and destruction. 
Each person during the cem ritual should express mutual consent in many ritualistic ways such as then shaking hands and kissing, praying for pardon. The following example ${ }^{3}$ is a spiritual leader (dede) reminding the hearth (ocak) principles in an initiation ritual;

"O, Allah. Thanks! If you poured something, you should then fill it up again; If you made somebody cry you should make them laugh. If you break a heart, you should conciliate. You should walk in the right way. Do not hurt your friend. You should be willing to devote yourself to the guide. Do not lie. Do not eat forbidden food. Do not commit adultery. Do not take up a thing that your hand has not laid down. Do not tell what you have not seen. Come not, come not, turn not, turn not, the property of those who come, the soul of those who turns. In your worship, do not associate anything or anyone with God (sirk). That is impossible in the way of Muhammed Ali. Are the Four Doors and the Forty Duties, true?"

The ritual of reintegration of the deviant is managed by the spiritual leaders (dede) whose acts are like a judge, during the ritual. After a believer became a deviant, his spiritual leader manages the ritual to reconvert his status from deviant to the believer (talip). If a spiritual leader becomes a deviant, the reintegration ritual is performed by another one who remains at the highest hearth (ocak). Hence, there is a hierarchical structure among the Alevi ocaks. It is known as "Hand in hand, hand in God". That is a powerful indicator that demonstrates just how important communication is between persons and hearth (ocaks). There are intra and intergroup relationships between the believers-leaders- guide (talip-dede-rehper) of each hearth (ocak) and the other hearth (ocak)s. According to a hierarchical structure, many hearths (ocaks) belongs to the Hac1 Bektaş Veli Ocak, but many of them remain independent. For example, Tahtac1 Alevis have a hierarchy within their hearth (ocaks) that known Yanyatır Ocak and Haci Emirli Ocak (Kayhan Kılıç, 2019: 189).

In Alevism, there is only one way to make peace which is performing the ritual that is the reintegration of deviant (düsskün kaldırma kurbanı). The deviant person

3 In original Turkish language: "Allah, Eyvallah! Kapısında döktügünüz varsa doldurun, ağlattıgınız varsa güldürün, yıktığınız varsa kaldırın, doğru gezin, dost gönlünü incitmeyin, Mürșidinize teslim-i riza olun. Yalan söylemeyin, haram yemeyin, zina etmeyin. Eliniz ile koymadığınızı almayın, gözünüz ile görmediğinizi söylemeyin. Gelme gelme, dönme dönme, gelenin malı, dönenin canı. Şirk ile ibadet olmaz Muhammed Ali yolunda, Dört Kapı, Kırk Makam hak mı?" 
should provide a sacrifice and distribute food (lokma) to apologize for the ancestors and the community. If rituals about ostracism are not remaining in a particular ocak, there might be a change in the traditional structure. Although it is challenging to perform these rituals due to today's social and economic conditions, ostracism is one of the functional ways to save ocak order. The Alevis have challenges to perform rituals related to düskünlük, even in a traditional context. Alevis perform other rituals, but it seems they have been removing düskünlük from their ritual cycle.

While talking about Istanbul, I evaluate the migration looking from the city context where the change happened. The Alevism in the city affects performances in the countryside. Alevis migrated to the city center, but their relations continue with their relatives who live in rural areas. Such that, those who live in urban or the rural do not want to answer questions about dïskünlük. Individuality, education, economical causes differences amongst the believers. Equality among people has deteriorated. If a person has status, prestige and wealth in the city society, it is unrealistic to declare them as deviant. I observed that a deviant person was forgiven without performing a ritual of reintegration of deviants (düşkün kaldırma) by grant compensation. They thought that this did not threaten security, but that it supported peace.

During my fieldwork studies, I did not observe the reintegration of deviant rituals. However, I noted several individuals are away from the community because people are not communicating with them. Hence, Alevis have their own rules and regulations to carry their belief from generation to generation. Those rules and regulations are not only religious but also cultural. It seems Alevis are not performing that ritual, but they are relatively following the rules in social and cultural context to maintain peace in their community. However, the gözcü who keeps watch and disciplines the participants stands near and to the right of the door. He does not allow strangers and deviants to participate in the ritual. This is possible in rural areas because people know each other. In the city context, Alevis allow people who want to participate in their rituals, even Sunnis.

\section{Entangled Alevi Identity}

There are two main reasons why the Alevi identity has become entangled. Firstly, Alevis' mood and motivation carry the cosmic framework in which symbols and meanings related to their belief has changed in city life. Secondly, when the city's Alevis reunited in new places, they could not create an independent and nature 
restructuring because of the sophisticated quality of city life, the destructive effect of political debates and the growing fear of Islam throughout the world.

Starting with the first one, the Alevi belief is shaped by symbols, meanings, and practices that enable them to experience, like other beliefs such as Native Americans (Fikes, 2010). According to Asad (1983: 237-259) "symbolic meanings linked to ideas or general order (expressed through either or both rite and doctrine)". For example, two of the twelve services are individual, the câr and the ablution of the congregation (tarikat abdesti). The câr is a broom with a short handle. Those services mean symbolically and ritualistically clean up the place where cem ritual performs. Metaphorically, those services also cleanse the hearts of the participants. Here symbols are conception itself (Asad, 1983: 117). It is sometimes an aspect of reality, sometimes of its representation. However, if there is no intrinsic connection with empirical events and the symbols, participants may not keep the symbols (Geertz, 1973: 91). It seems symbols are not able to "establish powerful, pervasive and longstanding moods and motivations" (Geertz, 1973: 90) in the city centers. The patterns of religious moods and motivations, the possibilities for religious knowledge and truth, have all varied for the believers. There may be eternal spiritual truths, but the meaning and the access of Alevis are different. It is sometimes an aspect of reality, sometimes of its representation.

In second, Alevi institutions have played an essential role while Alevis reconfiguring their identity. Alevis can find the writings, decorative objects and pictures related to Alevism in Alevi institutions. Many published books have affected the Alevis, who mostly have a conflict with traditional Alevism, significantly. Riza Y1ldirım (2012: 156-157) divides those publications into two; first pioneers whose writings are based on Alevi faith, other books that the leftist movement influenced may identify antifaith Alevi literature. For example, Ay Y1ldız Publishing, founded by Sefer Aytekin, Can Publishing, founded by Adil Ali Vaktidolu, has published books on faith. According to Riza Yildirım, the 1960s, leftism has begun to affect Turkey, and the Alevis have distance from their tradition in the urban. Nationalist theses should also be added as a third category. In nationalist theses, it is claimed that the Alevis were Christians who converted to Islam and that they were originally Turkish and Muslum or Kurdish (Bahadir, 2003: 1999-249). 
The considerable debate has launched concerning the Alevi identity since the release of "Alevis without Ali" (Bulut, 1997). Faik Bulut first proposed the concept of Alevism without Ali: a writer well-known for his work about Kurds, Palestine, and Islam. Bulut (1997) advocated that Ali was not, in fact, the idealized person that the Alevis believed him to be. Faik Bulut participated in popular TV and radio broadcasts to introduce his book. His argument was found quite radical by many Alevis. Many Alevis discussed his arguments and struggled along with him. His argument was supporting the idea that Alevism was a unique belief and lifestyle but, outside of Islam.

According to Ylldirım, the writings of Faik Bulut did not have a big impact on the Alevi community. I disagree, and I think it affects especially the young people of that period. During my ethnographic studies, I have recorded that some of the young Alevis thought that their beliefs, religious performances, and lifestyles placed them far from Islam. On the other hand, some of the Alevis were adopting the writings of Faik Bulut and organizing conversations for him. This book has been included in the Karacaahmet library when it was first published in 1997. It is also available at the Toronto Alevi Cultural Center.

According to my interviews, Alevi institutions had offered this book to the Alevis because if read by Alevis, it could develop a counterargument. However, the urban Alevis, and especially young Alevis did not know the Alevi tradition, ocak system and they were not able to discuss what they read.

In 1998, at the invitation of Ali Aktaş, (1998), the authors, among whom were academics, published a book called "Is that possible Alevism Without Ali?". That was the counterargument of the Bulut's publishing. They thought that he was not professionally versed in Alevism. He could not claim that Alevis were not Islam. They compared themselves with more popular versions of Islam. They criticized the book and found it to be non-academic. However, their books were not known among the Alevis in Istanbul. That book is not available today. But Bulut's book can still be purchased online.

In the book, Faik Bulut said, Hz. Ali was an Islamic warrior was killing many people for jihad. Alevism is a humanistic belief, there was no jihad in Alevism. How do Alevis accept such a person as holy? Therefore, Alevis interpreted Ali differently. The problematic point in Faik Bulut's book is, historical sources are kept above the 
narratives and that the oral tradition is underestimated. In Alevi narratives, Ali has wisdom and he is one of the most equitable person in Islam. Ali is an ancestor who has an important place in the common historical and cultural memory of Alevis.

There is a ghazi/dervish cult in Alevism. Thus, in Alevi belief, many holy persons belong to those called ghazi/saint who is believed to have been endowed with supernatural powers. Ghazis or warriors who have fallen in the fight against the infidel, generally either 'Arabs' of the early centuries of Islam or heroes of the Turkish conquest. For example, with the arrival of Turks at Anatolia, we see that Battal Gazi ${ }^{4}$, an Arabic Commander and soldier, was turned into a Turkish warrior and then a Saint (Gazi-Veli). This influence and reputation on the Turks were so high that there are seven cemeteries of Seyyid Battal Ghazi in Anatolia, which are thought to be equally holy. On behalf of Seyyid Battal Gazi, the ocak was established around the Seyitgazi district in Eskisehir. Seyyid Battal Gazi is known as a prominent herowarrior who acted nobly in the period of Anatolia's being Turkized amongst Alevis in Istanbul. Another example is Seyyid Ali Sultan who played an important role in the Turkish and Islamic incorporation of the Rumeli (Thrace). During the XIV century and specifically, the period of Bayezid I, he established his dervish lodge in Dimetoka. Seyyid Ali Sultan is one of the "early missionaries of the Bektashi way." (Birge, 1965: 51). In Istanbul, Alevi institutions have organized tours to the dargah of ghazi / dervishes in Turkey. Those tours have the pilgrimage meaning for Alevis. In recent years, one of the Alevi institutions Cem Vakfi has been organizing 'pilgrimages' to Iran. Hence, many spiritual leaders (dede) have visited the tomb of Imam Ali and many holy places in Iran.

The issue here is not the books which discuss Ali and Alevism, but the effects of them on the Alevi identity that is becoming entangled. According to the interviews, it seemed the leftist and anti-belief publishing had been especially affecting Alevi youth. The place that Alevi identity has become enmeshed in a labyrinth of socio-political obstacles and the challenges and pressures instigated by Sunni and Alevi institutions. What is emerging is a fractured, entangled identity. Moreover, discussions resulted in a schism amongst the Alevis; Alevis in Islam/outside of Muslims. Before going any further, I shall now continue to explain all the other arguments on this topic.

4 Say, Y., Battalname, available on the website http://www.aleviakademisi.de/dosyalar/ battalname.pdf 
I want to discuss about identity definitions in Alevi society. Some Alevi identify themselves as Muslim. They think of Alevism as an interpretation within Islam, but they think of themselves as non-Sunnis. Their belief is distantly related to Shiism in terms of loving Ahl-al Bayt. Those who think so express their commitment to Imam Cafer Sadik who was recognized as the sixth imam in Alevi belief. He established the sect of Caferi. The Buyruk, which is a well-known book, involves interpretations of Imam Cafer Sadik in the Alevi belief. There is an example ${ }^{5}$ from the cem rituals which was recorded both in city and rural areas:

I sacrifice myself as an offering to the son of Imam Bâkır

Do not follow Yazid

We must follow the way of Imam Cafer

This delil is lit for the persons who follow the direction of Imam Cafer

My pîr whispered his inspiration (instruction) in my ear

I am close to the greatness of Shah

My belief is in Cafer-i Sadik, gloriously

I came to the arena, the love God! (Allah)

In the ritual song (düvaz) delil or çırağ/ çerağ symbolizes the entity of Allah Muhammed Ali and their souls. Participants call the souls of Ah al-Bayt and the Twelve Imams. Hence, çıra $\breve{g}$ is an important part of the cem ritual. The çrağ is both a candle and the light of the candle's flame. In fact, they believe that God and all their ancestors watch over them. Metaphorically, the çrağ is the symbol of an awakened and enlightened soul, so participants use the term awaken çerağ (çırağ uyandırmak).

Other groups emphasize Alevi as an ancient belief of the Turks and their adoption of Islam. Alevism is based on the more verbal tradition that is in the Turkish language. So, it is believed that the Turks kept many old beliefs when they

$5 \quad$ The ritual song (düvaz) in the original Turkish language

Kurban olam Bâkır oğluna

Gitme Yezidin çı̆̆rına

Uyalım İmam Cafer yoluna

Uyanlar aşkına yandı bu delil

Pirim kulağıma eyledi telkin

Şahi velayete olmuşam yakın

Mezhebim Caferi Sadik methim

Allah dost eyvallah meydana geldim 
accepted Islam. Historians advocate that Alevis established connections between the new religion and their old beliefs that shamanism (Melikof, 2001: 75-81), (Yaman and Erdemir, 2006: 38), Inan (1986: 186). Koprulu (1999 (1922), 266). They define Alevis as a heterodox community that means Alevism is outside of Islamic orthodoxy. The popular belief was shaped by an environment that is far away from the center. Here, the corresponding functions of Alevis may be described as adjustive, adaptive, and integrative. However, historians especially considered that the Alevis were a heterodox community outside of Islamic orthodoxy, putting the Alevis in a difficult situation in the orthodox-heterodox conflict.

It is mentioned before, Alevi institutions opened up the stores that have writings, small decorative sculptures, necklaces, and illustrations. Carrying such objects in the 90s was very popular among Alevis. During my ethnographic studies, I have visited many of them. Everything was about the beliefs of the Alevis. Zulfikar patterned necklaces, and small statues were representing Pir Sultan Abdal. Alevis, especially coming from Europe, have visited and shopped here. Hence, these shops are still open but not as popular as in the 90s. In addition, Alevis found many musical works in cassette and CD formats there. Those music works represented Alevi music outside of the ritual music and semah are the backbones of all cem rituals. The minstrel (aş1k) plays instruments and sings religious songs. Hence, the role of the minstrel (asılk) is essential and their service is one of the twelve service (12 hizmet). The terminology of the minstrel is various amongst Alevi ocaks. However, the terms zakir, guvende, sazende or ası mostly used in Alevism. Depending on ocaks, different musical instruments such as tambourine and ritm accompany ritual songs even though baglama is a mostly known instrument (Ersal \& Kayhan-Kılıç, 2019: 14-20).

Alevis could have lost many things during their journey as much as other cultures because they have a very long history. The Alevi population was living far from each other along with Asia to Balkans like today. Their long history and diffusions are the main reasons to explain why there is diversity in ritual practices amongst the ocaks. Subsequently, Alevis have been losing their uniqueness and diversity because of deeply rooted social and political pressure, which come from both the state and society in different periods. However, Alevis accomplished to save their traditions throughout the centuries before cem rituals have been performed in the public sphere. They are inherently a self-enclosed community that feels need to protect themselves from others. However, Alevis are affected by the outside world today. 
Finally, televisions have broadcast cem rituals after the first Alevi channels began in 2005. Spiritual leaders (dede) and believers (talip) still gather around and watch the videos of Istanbul the standardized cem rituals every.

\section{Conclusion}

Many of the Alevi population have been moved from rural regions to urban cities due to socio-economic and political reasons, and they found themselves far from their homeland. Alevis have difficulties regrouping in new locations, reconstructing their religion, culture and self- identity. In this picture, Istanbul is a sophisticated and disorganized ethnic urban village that has never met the needs of the Alevis.

Alevis have moved from their sacred space to urban cities; for instance, in Istanbul, this can be defined as deterritorialized, which is the separation of social, cultural practices (such as people, objects, languages, or traditions) from a location. There is not only a physical but also cultural distance between their rural and urban life. In the urban context, their life can be defined as the hybrid. After resolving the ocak relations, they can't imagine their land and people. Hence, Alevis lose their cultures or localities through globalization in the cities, whereby now they are trying to find the local within the globe. They have lost the space that their belief and practices historically and spiritually attached. Alevis have had difficulty to find the relation between their origin and a distant place. However, many visitings are organized by Alevi institutions to sacred places. For example, Dargah of Haci Bektas Veli, Abdal Musa Sultan, Sucaeddin Veli Sultan, Seyyid Battal Gazi, the pilgrimages for Alevis and help them to figure out the nature of the Alevi belief.

Since the 1950s, Alevis have been losing their memory and self in a black hole. Alevis migrating from rural to urban areas are separated from the historical and ritualistic hearth-based (ocak) belief. All the symbols such as hearth (ocak), spirtual leader (dede), threshold, praying, belt (kemerbest/tı̆̆bend), awaken çırağ (çırăg uyandirmak), ritual songs, myths, brotherhood (musahip) relations, illustrations are differentiated from their conceptions. However, these symbols can still be associated in some way with their meanings and embodied in the practice. Other things that affect the power of symbols and the conceptions are religious moods and motivations, which are various amongst Alevis in the city. 
Alevis who are living in the city find difficulty to experience the theoretical knowledge. Acculturation has been interrupted and became problematic due to the migration. For instance, Alevis are losing their ocak community network system, also the effectiveness of rural religious leaders and their unique means of resolving community conflicts such as düşkünlük, and musâhiplik. Hence, spiritual leaders and Alevi institutions have the responsibility to clear-cut theological knowledge and ritualistic performance in the city. Although ritualistic symbols and conceptions are changing in the Alevi memory and losing their power, Alevi massacres have functions such as keeping the society together and uniting them in a common feeling. At this point, Alevi associations have the authority to organize activities and commemorations to keep these massacres alive in the memory of the community.

In the urban context, the Alevi population have re-convene around the Alevi institutions to confirm their identity. However, the power of Alevi belief is differently distributed and has a different thrust amongst Alevis. Each Alevi institutions have different ways of shaping the knowledge in different categories and making it available. There are differences between Pir Sultan Abdal Alevi associations and Cem Vakfi in terms of approaches to the reproduction of the Alevi theology in the city context. These differences between Alevi associations have reflected in rituals over time. For example, in addition to ritual changes such as the performance of the sacred dance elements of Mevlevi together with the Alevi whirling, some reinterpretations such as the reactions to daily politics, the authors invited for the discussions are the differences in approach among Alevi associations. The more recent inclusion of elements such as Mevlevi turning (semah) as Alevis continues to strategize ways to reconfigure their identity and achieve recognition. Alevi institutions prefer to provide their agenda, which is about the standardization of rituals. Also, many political involvements in institutions negatively affected the efforts of Alevis to struggle for their existence. Alevi institutions made the debates on Alevism even more complicated.

Alevis have struggled to re-product their community in multiple spaces of an ethnic urban village. However, Alevi identity has become enmeshed in a labyrinth of socio-political obstacles and the challenges and pressures instigated by Sunni and Alevi institutions. Alevis believe they must distinguish between state and religion. However, all relations between the religious form and secular shifting are determined 
by the Turkish state. Although religious structures were much more in rural life, it is not a problem for Alevis, one of the self-closed communities. But when they have migrated to the city, they have met with the modern state, modern production, modern science that affected their belief and practices. The pressure of both the state and the Sunni community is felt more in the city. Alevis have been subjected to other's judgments, and they are still awaiting tolerance from others. Alevis always protest the hate speech and discrimination waged against them. They complain about the longstanding services provided for the Sunnis by the Turkish regime. Hence, Alevis' struggle for justice and equality, both politically and legally, is maintained by Alevi associations.

Istanbul is like a large ethnic urban village. Alevis live together with other communities here. Hence, in the urban context, the Alevi community needed to exhibit more public displays to show their belief. They were influenced by different beliefs and made changes in their rituals. Hence, one of the considerable obstacles of city life is concerned with displaying more public. Alevis have expressed their religious performances in an unfamiliar environment and agenda. Their communal intimacy of regional modes of ritual practices and the guidance provided by a local religious specialist known are different and standardized from what they had before.

In conclusion, it is seen that the publications, especially those that claim Alevi nonIslamic, were presented to the Alevi community through Alevi associations and then society was split in two with these discussions. It is observed that the publications, especially those that claim the non-Islamic and anti-faith claims, were presented to the Alevi society by Alevi associations, and the community was divided into two with these discussions. However, it is necessary to understand the reasons why Alevis are entangled about their identity. Theatrical aspects of the urban cem and the debates amongst Alevis represent how Alevis lose their ocak-based belief, the meaning of spirituality, the land where their belief is attached due to the living in an urban realm, pressures of the Turkish state and Sunni institutions. Alevis have been losing their traditions, much like other traditional cultures such as Indigenous People in North America and Inuit in Alaska. What is emerging is a fractured, entangled identity, causing community conflicts.

In conclusion, Alevis must understand that it is challenging to find a belief that may be called pure around the world (Eliade, 1954, 2004). Eliade mentioned that there is "spiritual heritage." However, there must be enough traditional knowledge to 
separate the primordial phenomenon from the new. According to Spiro's (1966: 96) definition of religion as "an institution consisting of culturally patterned interaction with culturally postulated superhuman beings,". Hence, Alevis should not compare themselves to another belief and then not stigmatize. 
ABU-LUGHOD, Lila (1991). Writing Against Culture. In Recapturing Anthropology. by Richard G. Fox. (Ed.). Santa Fe: School of American Research Press. 466-479.

AKIN, Bülent (2016). "Erkân Güncelleme Denemelerine Dair Tespitler ve Çözüm Önerileri." II. Uluslararasi Baris ve Hosgoru Semposyumu, 08-10 October 2015. Nevşehir: Nevşehir Hacı Bektaş Veli Univeristesi Yayinlari. 416-436.

AKTAŞ, Ali (Ed.). (1998). Alisiz Alevilik Olur mu? İstanbul: Ant.

APPADURAI, Arjun (1991). "Global Ethnoscapes: Notes and Queries for a Transnational Anthropology." Recapturing Anthropology: Working in The Present. Richard G.Fox (Ed.). USA: University of Washington Press. 191- 210.

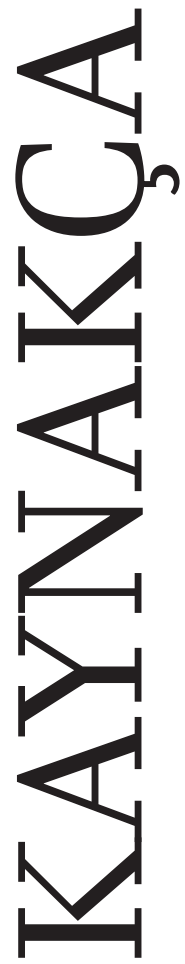

APPADURAI, Arjun (1996). Modernity at Large: Cultural Dimensions in Globalization. Minnesota: University of Minnesota Press.

ASAD, Talal. (Ed.). (1983). Anthropological Conception of Religion: Reflections of Geert: Man 18: 257-59.

ASSMANN, Jan. (2001). Kültürel Bellek: Eski Yülesek Kültürlerde Yaæl, Hatrlama ve Politik Kimlik. İstanbul: Ayrıntı Yayınları.

BAHADIR, Ibrahim (2003). "Alevilige Miliyetci Yaklasimlar ve Aleviler Üzerindeki Etkileri" Bilgi Toplumunda Alevilik. Ankara: Piramit Yayinlilik. 199246.

BARTH, Fredrik (Ed.). (2001). Etnik Gruplar ve Smırları. Çev. Ayhan Kaya, Seda Gürkan. İstanbul: Bağlam Yayıncllı.

BENNETT, Robbert (Ed.). (1989). Territory and Administration in Europe. London: Pinter.

BIRGE, John Kingsley (1965). The Bektashi Order of Dervishes. London: Luzac \& Co., Hartford, Conn., Hartford Seminary Press.

BOZKURT, Fuat (1999). "Aleviliğin Yeniden Yapılanma Sürecinde ToplumDevlet İlişkisi.” Alevî Kimliği T. Olsson, E. Özdalga vd.. (Ed.). İstanbul: Tarih Vakfi Yurt Yayınları.

BULUT, Faik. (1997). Alisir. Alevilik. Ankara: Doruk.

BURNS, Denye., HAMBLETON, Robin. and HOGGETT, Paul (1994). The Politics of Decentralisation: Revitalising Local Democracy. Basingstoke: Macmillan.

ÇIPLAK COŞKUN, N (2012). "Sosyokültürel Hayattaki Değişimlerin Alevî Cemlerine Etkisi: Alevî Kültür Dernekleri Mersin Şubesi Örneği." 2. Uluslararasi Taribten Bugune Alevilik Sempozyumu, 2010 Ankara. Ankara: Cem Vakfi. 222-235.

CLIFFORD, J. M., \& GEORGE, E., eds. (1986). Writing Culture: The Poetics and Politics of Ethnography. School of American Research Advanced Seminar.

CONNERTON, Paul (1999). Toplumlar Nasıl Ammsar. Trans. by Alaeddin Şenol. İstanbul: Ayrıntı Yayınları.

DIAMOND, Jared (1994). The Worst Mistake in the History of the Human Race. In Applying Cultural Anthropology: A Reader. Aaron Podolef-sky and Peter J. Brown, eds.. Mountain: View, CA: Mayfield Publishing Company. 105108

DRESSLER, Markus (2013). Writing Religion. NewYork: Oxford University Press. 
DRESSLER, Markus (2008). "Religio-Secular Metamorphoses: The Re-Making of Turkish Alevism." Journal of the American Academy of Religion 2008/76/2. 280-311.

DRESSLER, Markus (2006). "The Modern Dede: Changing Parameters for Religious Authorities in Contemporary Turkish Alevism". Speaking for Islam: Religious Authorities in Muslim Societies. Gudrun Kramer and Sabine Schmidtke. (Eds.). Leiden-Boston: Brill Academic Publishers. 269294.

DURKHEIM, Emile (1999). “The Elementary Forms of Religious Life”. Ritual \& Belief Readings in the Anthropology of Religion. David Hick (Eds.). Boston: McGraw-Hill College.

ELIADE, M. (1951, 2004). Shamanism Archaic Techniques of Ecstasy. Princeton, NJ, Princeton University Press.

ERSAL, Mehmet \& Kayhan-Kılıç, Seyhan. (2019). "Alevi Bektasi İnanç Sisteminde Semah Ritueli” Alevi Bektasi Semablari. Ankara: Baris Kitap.

ERSAL, Mehmet (2011). “Alevi İnanç Sistemindeki Ritüelik Özel Terimler: Musâhiplik”. Turkish Studies. 2011/6/1. 1058-1083.

ERSAL, Mehmet (2016). Alevilik: Kavramlar ve Ocak Sistemi Cubuk Havzası Örneği. Ankara: Gazi Üniversitesi Türk Kültürü ve Hacı Bektaş Veli Araştırma Merkezi Yayınları.

FIKES, Jay (2010). Unknown Huichol: Shamans and immortals, allies against chaos. Lanham, Md.: Rowman \& Littlefield Publishers.

GARLAND, David (1996). "Social Control." The Social Science Encyclopedia. Adam Kuper and Jessica Kuper (Eds.). NewYork: Routledge. 780-783.

GLASSIE, Henry (1995). “Tradition.” The Journal of American Folklore. 1995/108 (430). 395-412.

HANNERZ, Ulf (2003). "Being there... and there... and there! Reflections on multi-site ethnography”. Ethnography. 4: 201. s: 201-15.

HERSANT Jeanne et TOUMARKINE, Alexandre (2005). "Hometown organisations in Turkey: an overview." European Journal of Turkish Studies 2 | 2005, Retrieved from URL: http:/ /journals. openedition.org/ejts/397; DOI : 10.4000/ejts.397

INAN, Abdulkadir. (1986). Taribte ve Bugün Samanizm Materyaller ve Arastrrmalar. Ankara: Atatürk Kültür, Dil ve Tarih Yüksek Kurumu Türk Tarih Kurumu Yayınları.

KAYHAN KILIÇ, Seyhan (2014). Ritual Communication: A Case Study in Seyyid Ali Sultan Ocak's Cem Rituals. Istanbul University of Yeditepe Unpublished Doctoral Dissertation.

KAYHAN KILIC, Seyhan (2016). "Alevi-Bektași Geleneğinde Mitolojik Coğrafya Horasan.” II. Uluslararasi Barıș ve Hoşgörü Semposyumu, 08-10 October 2015. Nevşehir: Nevşehir Hacı Bektaş Veli Univeristesi Yayinlari.

KUIPERS, C. Joel (1990). Power in Performance: The Creation of Textual Authority in Weyewa Ritual Speech. Philadelphia: University of Pennsylvania Press.

MASSICARD, Elise (2005). "Alevism in the 1960s: Social Change and Mobilization." Alevis and Alevism: Transformed Identities. Hege Irene Markussen (Ed.). Istanbul: ISIS Press: 109-135.

MÉLIKOFF, Irène (2003). "Bektashi/Kiz1lbash: Historical Bipartition and Its Consequences." Alevi Identitiy Cultural, Religious and Social Perspectives. Tord Olsson, Elizabeth Özdalga. (Ed.) Catharina Raudvere. İstanbul: Sweden Research Institude.

MILLER, B., ESTERIK, Penny. V., \& ESTERIK, John.V. (2010) "Kinship and Domestic Life." Cultural Anthropology. Toronto: Pearson Canada Inc. 202-203.

OCAK, A. Y. (1996). Babailer İsyan, Alevíliğin Taribsel Altyapısı Yabut Anadolu'da İslam-Türk Heterodoksisinin Teșekekiulï, Gen.2.baskı. İstanbul: Dergâh Yayınları. 77, 80-81. 
OCAK, Ahmet Yaşar (2001). Alevi-Bektaşi İnançlarmnn İslam Öncesi Temelleri. İstanbul: İletişim Yayınları.

PADDISON, Ronan (2001). Communities in The City. Handbook of Urban Studies. SAGE Publications Ltd. 194-206.

RELP, E (1976). Places and Placeness. London: Pion Ltd.

Say, Yağmur (Ed.). (2009). Türk Islam tarihinde ve geleneginde Seyyid Battal Gazi ve Battalname. Eskişehir: Eskişehir Valiliği.

SPIRO, Melford (1966). "Religion: Problems of Definition and Explanation" Anthropological Approach to the Study of Religion. Michael Banton (Ed.). London: Routledge.

STRAUSS, Claude Levi (1969). The Elementary Structures of Kinship. Trans. by J.H. Bell, J.R. Von Sturmer, and Rodney Needham. Boston: Beacon Press.

SUBAŞI, Necdet (2002). "Türk Modernleşmesi ve Alevîlik”. Folkor/Edebiyat. Alevîlik Özel Sayısı. I, C. VIII. 2002/XXIX. 91-122.

TÜRKDOĞAN, Orhan (1995). Alevî-Bektaşî̉ Kimliği: Sosyo - Antropolojik Araştırma. İstanbul: Timaş Yayınları.

TURNER, Victor (1969). The ritual process: Structure and anti-structure. New York: Aldine de Gruyter. WADE, Davis (2009) The Wayfinder. Library and Archives Canada Cataloguing Publication.

WAGNER, Roy (1981) The Invention of Culture. Chicago: University of Chicago Press.

WALZER, Michael (1995). Toward a Global Civil Society. Oxford: Berghahn Books.

WEBER, Max (1993) The Sociology of Religon. Boston: Beacon Press.

WHITE, Paul J. \& JONGERDEN, Joost (2003). Turkey's Alevi Enigma: A Comprehensive Overview. Boston: Brill. 5-6, 53-56.

YAMAN, Ali \& ERDEMIR, Aykan (2006). Alevism-Bektashism A Brief Introduction. England Alevi Cultural Centre and Cemevi. Istanbul: Horasan Press.

YAMAN, Ali (2009). "Geçmişten Günümüze Dedelerin Misyonu ve Değişim (Mission of Dedes from Past to Present and Change". DEM Dergi (Değerler Eğitimi Merkezi Dergisi). 2009/6. 30-38.

(2011). "Alevilikte Ocak Kavramı: Anlam ve Tarihsel Arkaplan (The Concept of Ocak Term in Alevism: Meaning and Historical Background)". Türk Kültürü ve Hacı Bektas Veli Arastırma Dergisi. Gazi Üniversitesi Türk Kültürü ve Hacı Bektaş Veli Merkezi. 2011/60. 43-64.

(2014). "Geçmişten Günümüze Alevi Ocaklarında Değişime Dair Sosyo-Antropolojik Gözlemler.” Türk Kültuirü ve Hacı Bektass Veli Arasstrma Dergisi. Gazi Üniversitesi Türk Kültürü ve Hacı Bektaş Veli Merkezi. 2012/63. 17-38. Retrieved from https://yolpedia.eu/wp-content/ uploads/2019/05/

YILDIRIM, Rıza (2012). "Geleneksel Alevilikten Modern Aleviliğe: Tarihsel Bir Dönüşümün Ana Eksenleri.” Türk Kültürü ve Hacı Bektass Veli Arașttrma Dergisi. Gazi Üniversitesi Türk Kültürü ve Hacı Bektaş Veli Merkezi. 2012/62. 135-162. 